\title{
Analysis of Competitiveness and Complementarity of China-Vietnam Agricultural Product Trade under the Background of "the Belt and Road"
}

\author{
Zhiguang Guo \\ Business School \\ Sichuan Agricultural University \\ Dujiangyan, China
}

\author{
Hong Luo \\ Business School \\ Sichuan Agricultural University \\ Dujiangyan, China
}

\begin{abstract}
Under the background of "the Belt and Road", based on the data in the UN Commodity Trade Statistics Database, the status quo of China-Vietnam agricultural product trade is analyzed in this paper, the export similarity index, the revealed comparative advantage index, the trade complementarity index, the inter-industry and intra-industry trade complementarity index are adopted to analyze the competitiveness and complementarity of agricultural product trade between China and Vietnam from 2006 to 2016. It's found in study that the trade volume of China-Vietnam agricultural products has continuously increased, but China has been in a deficit state for a long time; from the perspective of competitiveness and complementarity, the overall complementarity of China-Vietnam agricultural product trade is relatively low, but there is a two-way trade relation between some types of agricultural products. China-Vietnam agricultural product trade is dominated by intra-industry trade and supplemented by inter-industry trade, and the overall intraindustry China-Vietnam trade complementarity is higher than that of inter-industry trade complementarity.
\end{abstract}

Keywords-"The Belt and Road"; agricultural product trade; competitiveness; complementarity

\section{INTRODUCTION}

Vietnam, known as the "Gold Mountain and Silver Sea", is bordered by Yunnan and Guangxi in China. The ChinaVietnam borderline is longer than 1400 kilometers. The adjacency of geographical location has greatly promoted the development of bilateral trade between the two countries. Since the normalization of diplomatic relations between China and Vietnam in 1991, the scale of trade between the two countries has continued to grow rapidly. In particular, since "the Belt and Road" strategy was implemented in 2010, the economic and trade cooperation between China and Vietnam has developed rapidly and the bilateral trade volume has hit record highs. In 2016, China-Vietnam bilateral trade volume reached USD 98.2 billion. China has been Vietnam's largest trading partner for 13 consecutive years. It is not only the largest source of imports, but also the largest export market for Vietnam's agricultural products, and Vietnam surpasses Malaysia to become China's largest trading partner in ASEAN.
According to the data analysis of the UN Commodity Trade Statistics Database, the total trade volume of China's agricultural products increased from USD 84.19 billion in 2006 to USD 230.334 billion in 2016, with an increase of 2.74 times. The total trade volume of Vietnam's agricultural products increased from USD 13.714 billion in 2006 to USD 43.676 billion in 2015, with an increase of nearly 3.18 times. This shows that agriculture is still an important industry for both countries, and they both still attach importance to the development of agricultural product trade. With the introduction of "the Belt and Road" strategy in 2010, it has greatly promoted the development of China's trade with countries along the route, which has a great impact on China's trade of agricultural products with countries along the route. agricultural product trade and cooperation plays an important role in bilateral trade. In such context, studying the competitiveness and complementarity of China-Vietnam agricultural product trade has certain practical significance.

In studies on the competitiveness and complementarity of product trade, scholars mostly use the revealed comparative advantage index, the export similarity index and other empirical comparative indices to study the trade situation between China and ASEAN, West Asia, South Asia, Central Asia, and the United States. There is less study on competitiveness and complementarity of China-Vietnam agricultural product trade. In this paper, not only the several important trade indices mentioned above are adopted, but also the revised intra-industry, intra-industry trade complementarity indices proposed by Chen Xiulian (2011) in the study of China-ASEAN service trade are used for reference, so as to make a more comprehensive and in-depth analysis of the agricultural product trade between China and Vietnam.

Based on the background of "the Belt One Road", this paper first analyzes the changes in the trade volume of agricultural products between China and Vietnam, and the proportion of the agricultural product trade in the two countries and ASEAN trade from 2006 to 2016, to understand the status quo of China-Vietnam agricultural product trade; then it uses the export similarity index and the revealed comparative advantage index to analyzes the competitiveness 
of China-Vietnam agricultural product trade; next it uses the comprehensive trade complementarity index, inter-industry and intra-industry trade complementarity indices to analyze the complementarity of China-Vietnam agricultural product trade; finally it analyzes the situation and draws conclusions, and proposes policy and recommendations to promote ChinaVietnam agricultural product trade.

\section{Status Quo of ChINA-VIETNAM BILATERAL TRADE OF AGRICULTURAL PRODUCTS}

\section{A. Trade Volume of Agricultural Products}

China and Vietnam have always been traditional agricultural countries, and agricultural product trade plays an important role in the bilateral trade. As shown in Figure 1, the total trade volume of China-Vietnam agricultural products increased from USD 381 million in 2006 to USD 4.008 billion in 2016, with an average annual growth rate of $25.8 \%$, and showed a double growth trend in import and export trade. The growth rate of agricultural products from 2009 to 2010 reached $50.59 \%$, partly due to the promotion of trade policies of the two countries in 2010, such as "the Belt and Road" proposed by China and the official establishment of ChinaASEAN Free Trade Area. However, in the trade of agricultural products between China and Vietnam, China is basically in a trade deficit, and the level of deficit is in fluctuations. On the one hand, due to the unbalanced supply and demand of China's domestic agricultural products in recent years, under the strategy of the Belt and Road, China has met its increasing domestic demand for agricultural products by importing a large number of agricultural products from countries along the route. On the other hand, with the appreciation of Renminbi, the rising costs of labor and raw materials have led to an increase in the cost of agriculture.

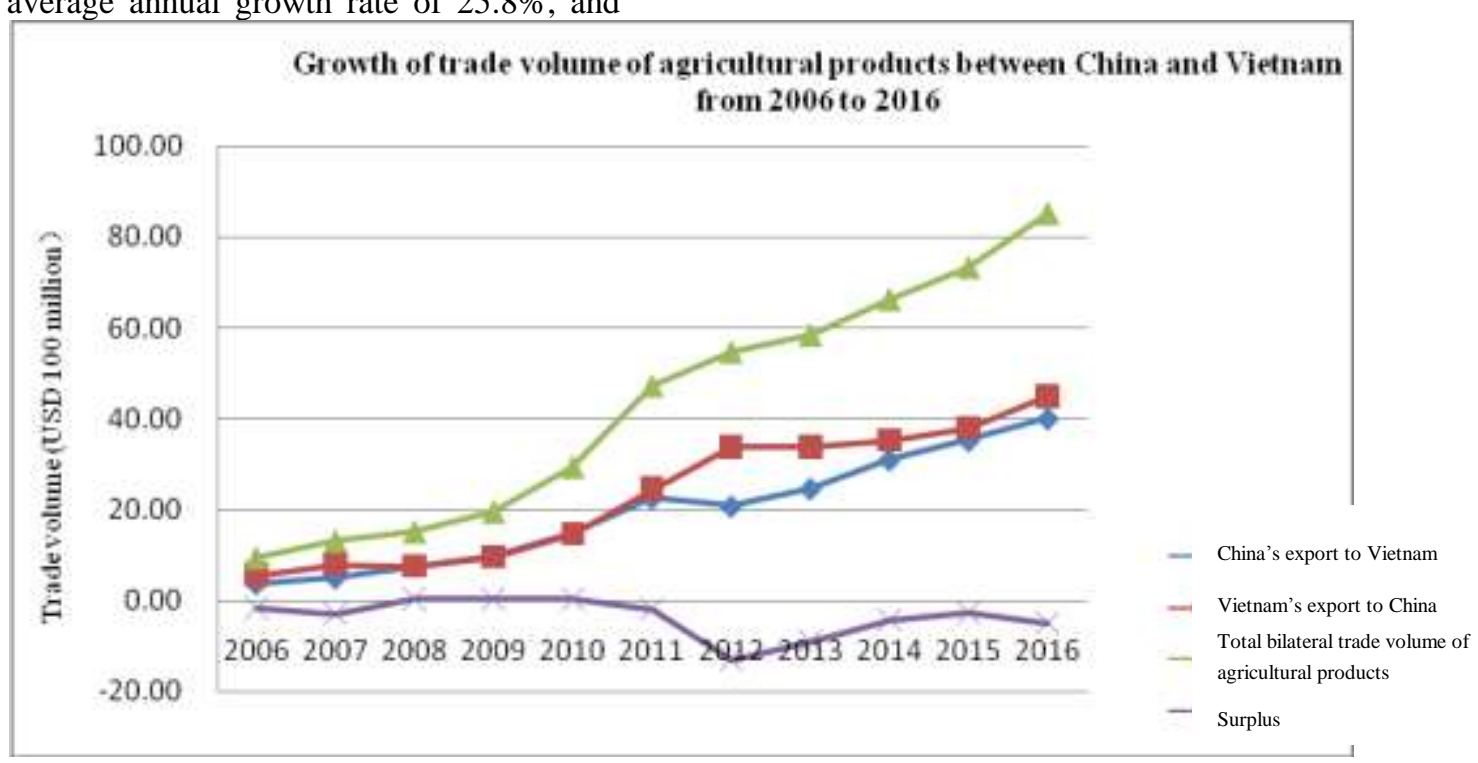

B. The Proportion of Agricultural Product Trade in the Trade Between the Two Countries

It can be seen from "Table I" that the proportion of ChinaVietnam agricultural product trade in bilateral product trade is relatively small, averaging only $9.15 \%$ per year. However, since agricultural products are used as primary products, their import and export value cannot be compared with other products. Specifically, China's export of agricultural products to Vietnam accounts for 5.6\% of its export products each year, and it has been relatively stable in recent years. Vietnam's export of agricultural products to China account for $19.19 \%$ of its export products, but it has been declining year by year recently, from $22.43 \%$ in 2006 to $12.12 \%$ in 2016 .
TABLE I. THE PROPORTION OF CHINA AND VIETNAM's AgRICULTURAL PRODUCT TRADE IN BILATERAL TRADE

\begin{tabular}{clll}
\hline Year & $\begin{array}{c}\text { Total Bilateral } \\
\text { Trade of } \\
\text { Agricultural } \\
\text { Products (USD 100 } \\
\text { Million) }\end{array}$ & $\begin{array}{c}\text { Total Bilateral Trade } \\
\text { Volume of All Goods } \\
\text { (USD 100 Million) }\end{array}$ & $\begin{array}{c}\text { The Proportion of } \\
\text { Bilateral } \\
\text { Agricultural } \\
\text { Product Trade in } \\
\text { Bilateral Trade of } \\
\text { All Goods (\%) }\end{array}$ \\
\hline 2006 & 9.40 & 99.49 & 9.44 \\
2007 & 13.07 & 151.21 & 8.65 \\
2008 & 15.11 & 194.58 & 7.77 \\
2009 & 19.49 & 210.48 & 9.26 \\
2010 & 29.36 & 300.86 & 9.76 \\
2011 & 47.22 & 402.08 & 11.74 \\
2012 & 54.65 & 504.42 & 10.83 \\
2013 & 58.43 & 654.78 & 8.92 \\
2014 & 66.26 & 836.36 & 7.92 \\
2015 & 73.29 & 958.49 & 7.65 \\
2016 & 85.15 & 982.66 & 8.67 \\
\hline
\end{tabular}




\section{Commodity Structure of Agricultural Product Trade}

From the perspective of export, most of China's agricultural products exported to Vietnam are concentrated in category 0 , with an annual average of $78.103 \%$. Specifically, they are mainly concentrated in category 05 (vegetables and fruits), which accounted for more than $70 \%$ of the exports of agricultural products in category 0 in 2016. The second is category 2 with an annual average of $19.45 \%$. Specifically, they were mainly concentrated in category 29 (animal and vegetable raw materials) and category 28 (textile fibers) in 2016. The total export of agricultural products in Category 0 and Category 2 is as high as $97.55 \%$. From the perspective of import, China's imports agricultural products imported from Vietnam are also concentrated in category 0 and category 2, with an annual average of $99.1 \%$. Specifically, there are category 05 , category 04 (grain and cereal products), category 23 (natural rubber) and category 24 (cork and wood). This indicates that China and Vietnam's import and export of agricultural products are basically the same in "Table II".

TABle II. COMmodity Structure of China-Vietnam Agricultural Product Tradeunit: \%

\begin{tabular}{|c|c|c|c|c|c|c|c|c|}
\hline \multirow[b]{2}{*}{ Year } & \multicolumn{4}{|c|}{ China's Exports to Vietnam } & \multicolumn{4}{|c|}{ China's Imports from Vietnam } \\
\hline & Category 0 & $\begin{array}{c}\text { Category } \\
1 \\
\end{array}$ & Category 2 & Category 4 & Category 0 & $\begin{array}{c}\text { Category } \\
1 \\
\end{array}$ & Category 2 & $\begin{array}{c}\text { Category } \\
4^{1} \\
\end{array}$ \\
\hline 2006 & 73.68 & 1.87 & 24.39 & 0.05 & 48.08 & 0.00 & 51.78 & 0.14 \\
\hline 2007 & 72.05 & 2.03 & 25.45 & 0.48 & 46.29 & 0.00 & 52.06 & 1.66 \\
\hline 2008 & 69.72 & 2.56 & 22.40 & 5.32 & 54.54 & 0.00 & 43.60 & 1.85 \\
\hline 2009 & 78.31 & 2.20 & 19.34 & 0.16 & 68.30 & 0.01 & 31.52 & 0.18 \\
\hline 2010 & 78.04 & 1.24 & 20.03 & 0.68 & 45.03 & 0.01 & 54.02 & 0.93 \\
\hline 2011 & 79.45 & 1.50 & 18.54 & 0.51 & 45.36 & 0.01 & 53.85 & 0.78 \\
\hline 2012 & 77.08 & 1.76 & 20.63 & 0.53 & 58.01 & 0.01 & 41.34 & 0.64 \\
\hline 2013 & 78.48 & 1.18 & 20.07 & 0.27 & 54.24 & 0.01 & 44.83 & 0.92 \\
\hline 2014 & 81.53 & 1.16 & 17.11 & 0.21 & 58.69 & 0.03 & 40.64 & 0.64 \\
\hline 2015 & 85.17 & 1.29 & 13.34 & 0.20 & 64.73 & 0.03 & 34.86 & 0.39 \\
\hline 2016 & 85.62 & 1.41 & 12.64 & 0.33 & 57.07 & 0.18 & 42.41 & 0.34 \\
\hline Mean & 78.10 & 1.65 & 19.45 & 0.79 & 54.58 & 0.03 & 44.63 & 0.77 \\
\hline
\end{tabular}

\section{Position of China-Vietnam Agricultural Product Trade in} China-ASEAN Trade

Among the 10 ASEAN countries, the major import and export countries of China's agricultural products trade are Vietnam, Thailand, Malaysia, and the Philippines, and the trade volume of agricultural products with other countries is relatively small. As can be seen from "Table III", the ratio of China-Vietnam agricultural product trade to China-ASEAN agricultural product trade has been increasing, from less than $10 \%$ in 2006 to $20.88 \%$ in 2016, indicating that the proportion of China-Vietnam agricultural product trade in China-ASEAN agricultural product trade has been increasing.
TABLE III POSITION OF CHINA-VIETNAM Agricultural PRODUCT Trade IN THE Agricultural PRODUCT TRADE BETWEEN CHINA AND ASEAN

\begin{tabular}{|c|c|c|c|}
\hline Year & $\begin{array}{c}\text { Total Trade } \\
\text { Volume of } \\
\text { Agricultural } \\
\text { Products Between } \\
\text { China and } \\
\text { Vietnam (USD } \\
100 \text { Million) }\end{array}$ & $\begin{array}{l}\text { Total Trade Volume } \\
\text { of Agricultural } \\
\text { Products Between } \\
\text { China and ASEAN } \\
\text { (USD } 100 \text { Million) }\end{array}$ & $\begin{array}{c}\text { The Proportion } \\
\text { of China- } \\
\text { Vietnam } \\
\text { Agricultural } \\
\text { Product Trade } \\
\text { In China- } \\
\text { ASEAN } \\
\text { Agricultural } \\
\text { Product Trade } \\
(\%)\end{array}$ \\
\hline 2006 & 9.40 & 128.84 & 7.29 \\
\hline 2007 & 13.07 & 164.46 & 7.95 \\
\hline 2008 & 15.11 & 200.87 & 7.52 \\
\hline 2009 & 19.49 & 186.07 & 10.48 \\
\hline 2010 & 29.36 & 270.61 & 10.85 \\
\hline 2011 & 47.22 & 388.98 & 12.14 \\
\hline 2012 & 54.65 & 382.93 & 14.27 \\
\hline 2013 & 58.43 & 390.83 & 14.95 \\
\hline 2014 & 66.26 & 413.99 & 16.00 \\
\hline 2015 & 73.29 & 402.12 & 18.23 \\
\hline 2016 & 85.15 & 407.75 & 20.88 \\
\hline
\end{tabular}

\footnotetext{
${ }^{1}$ Note: The agricultural products mentioned in this paper are commodities in the four major categories with 0 , 1,2 , and 4 as the first code under category SITC Rev. 3, excluding commodities in category 27 and 28 with 2 as the first code, including category 0 (foods and live animals), category 1 (beverages and tobacco), category 2 (non-edible materials, except fuels), category 4 (fossil fuels, lubricants and related raw materials). All notes in this table apply to this paper.
} 


\section{ANALYSIS ON THE COMPETITIVENESS OF CHINA- VIETNAM AGRICULTURAL PRODUCT TRADE}

\section{A. Export Similarity Index (ESI)}

Finger and Kreinin (1979) first proposed the product export similarity index when studying the export similarity in the commodity field. Glick and Rose (1998) proposed the market similarity index based on Finger and Kreinin, which is now used to measure the level of similarity of the two countries' products exported to the world market or particular markets. This paper uses the market similarity index proposed by Glick and Rose. The formula is:

$$
E S I_{a b c}=\left\{\sum_{k}\left[\left(\frac{x_{a c}^{k} / x_{a c}+x_{b c}^{k} / x_{b c}}{2}\right)\left(1-\left|\frac{x_{a c}^{k} / x_{a c}-x_{b c}^{k} / x_{b c}}{x_{a c}^{k} / x_{a c}+x_{b c}^{k} / x_{b c}}\right|\right)\right]\right\}
$$

The calculation results of the similarity indices of ChinaVietnam agricultural products in the world, the American, the EU, and the Japanese markets from 2006 to 2015 are shown in Table 4 . The similarity indices of agricultural product exports in particular markets are higher than 40 in each year, indicating that the competition among China-Vietnam agricultural products is intense. Especially the export similarity index is basically higher than 50in the world market, the American and Japanese markets in each year, besides, the index is basically stable around 50 in the American and Japanese markets, and is increasing year by year in the world market. This shows that the export competition of agricultural products between the two countries in the world market is increasingly fierce. The overall product structure of ChinaVietnam agricultural products is very similar in particular markets, which reflects the relatively high degree of competition between agricultural products of the two countries.

TABLE IV. EXPORT SIMILARITY INDEX OF CHINA-VIETNAM Agricultural Product TRADE

\begin{tabular}{ccccc}
\hline Year & $\begin{array}{c}\text { World } \\
\text { Market }\end{array}$ & $\begin{array}{c}\text { American } \\
\text { Market }\end{array}$ & $\begin{array}{c}\text { EU } \\
\text { Market }\end{array}$ & $\begin{array}{c}\text { Japanese } \\
\text { Market }\end{array}$ \\
\hline 2006 & 53.69 & 48.08 & 41.07 & 56.72 \\
2007 & 53.67 & 49.94 & 41.86 & 53.20 \\
2008 & 52.63 & 51.69 & 42.14 & 51.99 \\
2009 & 55.27 & 53.97 & 44.59 & 55.56 \\
2010 & 54.65 & 52.69 & 43.68 & 52.30 \\
2011 & 53.15 & 51.20 & 42.10 & 48.18 \\
2012 & 53.55 & 50.09 & 41.85 & 49.46 \\
2013 & 54.25 & 50.71 & 43.67 & 47.96 \\
2014 & 55.13 & 51.51 & 43.08 & 49.04 \\
2015 & 56.15 & 51.19 & 44.15 & 45.82 \\
\hline
\end{tabular}

1 Note: $\mathrm{a}, \mathrm{b}$, and $\mathrm{c}$ in the formula represent the Country a, Country b, and Market $\mathrm{c}$, respectively, $\quad \mathrm{x}_{\mathrm{m}}^{\mathrm{k}} \mathbb{A}$ represents the proportion of the trade volume of the agricultural product in Category $\mathrm{k}$ in the total agricultural products exported from Country a to Market c. $\mathrm{x}_{\mathrm{bz}}^{\mathrm{k}} / \mathrm{represents} \mathrm{the}$ proportion of the trade volume of the agricultural product in Category $\mathrm{k}$ in the total agricultural products exported from Country b to Market $c$. The index is in the range of 0 to 100 . The greater the index, the more similar the agricultural product structure exported by the two countries to Market c, and the more intense the trade competition between the two parties. 
B. Revealed Comparative Advantage Index(RCA)

TABLE V. REVEaled Comparative AdVANTAge IndEX OF China-VIETNAM Agricultural Product Trade

\begin{tabular}{|c|c|c|c|c|c|c|c|c|c|c|}
\hline \multirow[b]{2}{*}{ Year } & \multicolumn{5}{|c|}{ China } & \multicolumn{5}{|c|}{ Vietnam } \\
\hline & $\begin{array}{c}\text { Catego } \\
\text { ry } 0\end{array}$ & $\begin{array}{l}\text { Categ } \\
\text { ory } 1\end{array}$ & $\begin{array}{c}\text { Catego } \\
\text { ry } 2\end{array}$ & $\begin{array}{c}\text { Catego } \\
\text { ry } 4\end{array}$ & $\begin{array}{l}\text { Comprehen } \\
\text { sive } \\
\text { agricultural } \\
\text { products }\end{array}$ & $\begin{array}{c}\text { Cate } \\
\text { gory } \\
0\end{array}$ & $\begin{array}{c}\text { Cate } \\
\text { gory } \\
1\end{array}$ & $\begin{array}{c}\text { Categor } \\
\text { y } 2\end{array}$ & Category 4 & $\begin{array}{l}\text { Comprehensiv } \\
\text { e agricultural } \\
\text { products }\end{array}$ \\
\hline 2006 & 1.25 & 0.37 & 0.73 & 0.24 & 0.35 & 1.27 & 0.16 & 0.80 & 0.04 & 2.42 \\
\hline 2007 & 1.25 & 0.37 & 0.76 & 0.14 & 0.40 & 1.29 & 0.14 & 0.79 & 0.08 & 2.92 \\
\hline 2008 & 1.22 & 0.4 & 0.85 & 0.21 & 0.36 & 1.3 & 0.15 & 0.72 & 0.11 & 2.82 \\
\hline 2009 & 1.20 & 0.43 & 0.82 & 0.15 & 0.37 & 1.29 & 0.19 & 0.65 & 0.11 & 2.53 \\
\hline 2010 & 1.24 & 0.43 & 0.74 & 0.13 & 0.37 & 1.24 & 0.21 & 0.84 & 0.11 & 2.65 \\
\hline 2011 & 1.24 & 0.43 & 0.79 & 0.13 & 0.38 & 1.24 & 0.20 & 0.88 & 0.15 & 2.54 \\
\hline 2012 & 1.24 & 0.46 & 0.76 & 0.14 & 0.36 & 1.26 & 0.23 & 0.77 & 0.21 & 2.26 \\
\hline 2013 & 1.23 & 0.43 & 0.76 & 0.16 & 0.35 & 1.21 & 0.27 & 0.87 & 0.19 & 1.93 \\
\hline 2014 & 1.20 & 0.45 & 0.81 & 0.16 & 0.34 & 1.26 & 0.24 & 0.69 & 0.19 & 1.85 \\
\hline 2015 & 1.20 & 0.52 & 0.75 & 0.17 & 0.34 & 1.24 & 0.26 & 0.74 & 0.22 & 1.59 \\
\hline
\end{tabular}

$$
R C A_{x a k}=\left(X_{a}^{k} / X_{a}^{t}\right)\left(X_{w}^{k} / X_{w}^{t}\right)
$$

The annual average RCA index of comprehensive agricultural products in Vietnam is 2.35 , and the index is greater than 1.8 in each year, indicating that Vietnam's agricultural products have a strong competitive advantage, but the index is declining year by year. Specifically, the competitive agricultural products are mainly concentrated in category 0 , which is the same as China's competitive agricultural products. The RCA index of China's agricultural product is below 0.8 in each year, indicating that the overall export competitiveness of China's comprehensive agricultural products is lower than that of the world agricultural products during the same period.

Through the analysis of the above two indices, we can see that China-Vietnam agricultural product trade has strong competitiveness both in the international market and in particular markets such as the American and the EU markets, and the export competitiveness of China's agricultural products is much lower than that of Vietnam's agricultural products in the same period. This shows that although China has always been a large agricultural country, it still has obvious contradictions in the agricultural product structure in terms of supply, for China's food demand is large, moreover, the reduction of China's arable land leaves the export competitiveness of Category 2 at a disadvantage in recent years. Therefore, China should make full use of "the Belt and Road" strategy, rectify the structure of our agricultural products, pay close attention to structural reforms on the supply side, and enhance the competitiveness of China's agricultural product exports.

\section{ANALYSIS OF THE COMPLEMENTARITY OF CHINA- VIETNAM Agricultural PRODUCT TRADE}

A. Overall Trade Complementarity Analysis (Trade Complementarity Index (Tci)) $T C I_{a b}=\sum_{k}\left[W_{k} \times R C A_{x a k} \times R C A_{m b k}\right]^{4}$ Where: $R C A_{m b k}=\left(M_{b}^{k} / M_{b}^{t}\right)\left(X_{W}^{k} / X_{w}^{t}\right)$

2 Note: represents the amount of agricultural products in category k exported by Country a, and represents the amount of all the agricultural

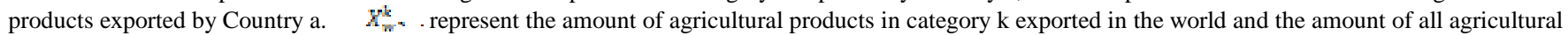
products exported in the world respectively.

3 Note: $\quad 1$ represents the amount of agricultural products in category $\mathrm{k}$ imported to country b, a represents the amount of all agricultural products imported to country b. $R C A_{a}$ is used to measure the comparative advantage of country a in product $\mathrm{k}$ and $R C A_{\mathrm{a}}$ is used to measure the comparative disadvantage of country $\mathrm{b}$ in product $\mathrm{k}$. 1 represents the weights, which is the proportion of the total trade of agricultural products in category $\mathrm{k}$ in the trade of all agricultural products in the world. $T C_{\mathrm{c}}$ is used to measure the degree of trade complementarity between the two countries, the greater the index, the greater the degree of trade complementarity between the two countries. 
TABLE VI. TCI INDEX OF CHINA-VIETNAM AGRICULTURAL PRODUCT TRADE

\begin{tabular}{|c|c|c|c|c|c|c|c|c|c|c|}
\hline \multicolumn{6}{|c|}{ Measured with Chinese Exports } & \multicolumn{5}{|c|}{ Measured with Chinese Imports } \\
\hline Year & $\begin{array}{c}\text { Catego } \\
\text { ry } 0\end{array}$ & $\begin{array}{c}\text { Categor } \\
y 1\end{array}$ & $\begin{array}{c}\text { Categor } \\
\text { y } 2\end{array}$ & Category 4 & $\begin{array}{c}\text { Compo } \\
\text { site } \\
\text { index } \\
\end{array}$ & $\begin{array}{c}\text { Catego } \\
\text { ry } 0\end{array}$ & $\begin{array}{c}\text { Category } \\
1\end{array}$ & $\begin{array}{c}\text { Categor } \\
\text { y } 2\end{array}$ & $\begin{array}{c}\text { Categor } \\
y 4\end{array}$ & $\begin{array}{c}\text { Compo } \\
\text { site } \\
\text { index } \\
\end{array}$ \\
\hline 2006 & 1.03 & 0.12 & 1.29 & 0.28 & 0.96 & 0.39 & 0.03 & 2.57 & 0.07 & 0.82 \\
\hline 2007 & 1.10 & 0.14 & 1.18 & 0.21 & 0.97 & 0.36 & 0.03 & 2.50 & 0.17 & 0.78 \\
\hline 2008 & 1.07 & 0.16 & 1.35 & 0.25 & 0.99 & 0.33 & 0.04 & 2.45 & 0.19 & 0.73 \\
\hline 2009 & 1.10 & 0.18 & 1.25 & 0.17 & 0.99 & 0.38 & 0.05 & 2.34 & 0.20 & 0.70 \\
\hline 2010 & 1.17 & 0.18 & 1.06 & 0.14 & 1.00 & 0.39 & 0.05 & 2.74 & 0.15 & 0.84 \\
\hline 2011 & 1.10 & 0.18 & 1.25 & 0.14 & 0.99 & 0.39 & 0.06 & 2.76 & 0.17 & 0.87 \\
\hline 2012 & 1.13 & 0.21 & 1.21 & 0.12 & 1.00 & 0.45 & 0.08 & 2.35 & 0.27 & 0.82 \\
\hline 2013 & 1.12 & 0.18 & 1.24 & 0.12 & 1.01 & 0.47 & 0.08 & 2.73 & 0.22 & 0.90 \\
\hline 2014 & 1.07 & 0.20 & 1.41 & 0.13 & 1.01 & 0.52 & 0.09 & 2.23 & 0.18 & 0.81 \\
\hline 2015 & 1.13 & 0.27 & 1.25 & 0.11 & 1.02 & 0.59 & 0.11 & 2.29 & 0.20 & 0.85 \\
\hline
\end{tabular}
with China's exports and imports. The trade complementarity index of China-Vietnam agricultural products in Category 2 is higher than 1 , indicating that there is a strong two-way trade complementarity of the agricultural products in this category between China and Vietnam. The trade complementarity indicesof the agricultural products in Category 0 measured with China's exports are all higher than 1 , and the trade complementarity indices measured with China's imports are lower than 1,so there is a strong single-way trade complementarity of agricultural products in category 0 between China and Vietnam. The trade complementarity of agricultural products in the other two categories is very low between China and Vietnam. Seeing from the composite index, although the trade complementarity index measured with China's exports has increased year by year, the composite indices of the two categories of standards are relatively small, indicating that the trade complementarity between China and Vietnam is relatively low. However, the trade complementarity index of agricultural products between China Vietnam is higher than that between China and the most other countries of ASEAN, which might be caused by the fact that climate difference between China and Vietnam and the similarity of the consumption demand determine the complementarity of agricultural product trade between the two sides to some extent.

\section{B. Analysis on the Inter-industry and Intra-industry Trade Complementarity of Agricultural Products between China and Vietnam}

Agricultural product trade is divided into inter-industry and intra-industry trade. In recent years, with the continuous upgrading of the product structure of trade, the increasing trade barriers and trade protection of agricultural products by countries, and the shift of modern agricultural production methods to economies of scale, the importance of intraindustry trade is growing. This paper uses Grubel Lloyd index to determine the type of agricultural product trade between China and Vietnam. The formula is as follows:
The G-L index of overall China-Vietnam agricultural product trade is higher than 0.5 in each year, basically close to 1 , indicating that China-Vietnam agricultural products are in intra-industry trade overall. From the perspective of various categories of agricultural products, the indices of agricultural products in category 0 and category 2 are higher than 0.5 , indicating that intra-industry trade predominates among the agricultural products in category 0 and category 2 . The annual index of agricultural products in category 4 is 0.62 , and it rose sharply from 2014 to 2016 from 0.44 to 0.92 . This indicates that China-Vietnam trade of agricultural products in category 4 is dominated by intra-industry trade. The trade of agricultural products in category 1 is dominated by interindustry trade.

This paper uses the revised inter-industry and intraindustry trade complementarity index proposed by Chen Xiulian (2011) for reference, who believes that the interindustry trade complementarity is caused by the comparative price advantage formed by different comparative advantages of natural resources, capital, and other factors between industries. However, the intra-industry trade complementarity is related to the different internal comparative advantages of different products in the same industry formed by the characteristics such as economies of scale, product heterogeneity, market size, and consumer demand. Therefore, by further subdividing the trade complementarity of agricultural products, we can understand the reasons for the complementarity of China-Vietnam agricultural products so that different measures can be taken for different complementarities. The calculation formula of the interindustry and intra-industry trade complementarity index is as follows: 
TABLE VII. G-L INDEX OF ChINA-VIETNAM AgRICULTURAL PRODUCT TradE

\begin{tabular}{llllll}
\hline Year & Category 0 & Category 1 & Category 2 & Category 4 & $\begin{array}{c}\text { Comprehensive Agricultural } \\
\text { Products }\end{array}$ \\
\hline 2006 & 0.976 & 0.004 & 0.488 & 0.401 & 0.813 \\
2007 & 0.995 & 0.001 & 0.474 & 0.309 & 0.777 \\
2008 & 0.866 & 0.002 & 0.689 & 0.508 & 0.988 \\
2009 & 0.915 & 0.007 & 0.776 & 0.944 & 0.984 \\
2010 & 0.726 & 0.020 & 0.546 & 0.852 & 0.994 \\
2011 & 0.766 & 0.010 & 0.481 & 0.749 & 0.958 \\
2012 & 0.900 & 0.020 & 0.470 & 0.674 & 0.762 \\
2013 & 0.973 & 0.028 & 0.493 & 0.351 & 0.844 \\
2014 & 0.900 & 0.053 & 0.540 & 0.439 & 0.936 \\
2015 & 0.901 & 0.040 & 0.524 & 0.643 & 0.962 \\
2016 & 0.857 & 0.254 & 0.419 & 0.929 & 0.942 \\
\hline
\end{tabular}

\section{Calculation formula}

Inter-industry trade complementarity index for a certain category of agricultural products: $\mathrm{C}_{\mathrm{abk}}=\left|\mathrm{CA}_{\mathrm{kak}}\right| \times\left|\mathrm{CA}_{\mathrm{mbk}}\right|$

Inter-industry trade complementarity index for all agricultural products: $\mathrm{TC}_{\mathrm{abk}}=\Sigma_{\mathrm{k}} \mathrm{W}_{\mathrm{k}} \times\left|\mathrm{CA}_{\mathrm{xak}}\right| \times\left|\mathrm{CA}_{\mathrm{mbk}}\right|$

Inter-industry trade complementarity index for a certain category of agricultural products: $\mathrm{TI}_{\mathrm{abk}}=\left\|1-\mathrm{CA}_{\mathrm{xak}}\right\| \times\left\|1-\mathrm{CA}_{\mathrm{mbk}}\right\|$

Inter-industry trade complementarity index for all agricultural products: $\mathrm{TTI}_{\mathrm{abk}}=\Sigma_{\mathrm{k}} \mathrm{W}_{\mathrm{k}} \times\left\|1-\mathrm{CA}_{\mathrm{xak}}\right\| \times\left\|1-\mathrm{CA}_{\mathrm{mbk}}\right\|$

TABLE VIII. TRADE COMPLEMENTARITy INDEX FOR VARIOUS TyPES OF AGRICUlTural PRODUCTS OF CHINA AND VIETNAM

\begin{tabular}{llllll}
\hline Year & Category 0 & $\begin{array}{c}\text { Categor } \\
\text { y 1 }\end{array}$ & Category 2 & Category 4 & $\begin{array}{c}\text { Comprehensive } \\
\text { Agricultural } \\
\text { Products }\end{array}$ \\
\hline 2006 & 0.13 & 0.10 & 0.24 & 0.69 & 0.18 \\
2007 & 0.12 & 0.10 & 0.20 & 0.78 & 0.17 \\
2008 & 0.13 & 0.11 & 0.22 & 0.67 & 0.18 \\
2009 & 0.10 & 0.10 & 0.26 & 0.70 & 0.17 \\
2010 & 0.08 & 0.06 & 0.16 & 0.69 & 0.13 \\
2011 & 0.10 & 0.03 & 0.17 & 0.49 & 0.14 \\
2012 & 0.09 & 0.02 & 0.21 & 0.46 & 0.11 \\
2013 & 0.07 & 0.01 & 0.18 & 0.44 & 0.13 \\
2014 & 0.08 & 0.00 & 0.26 & 0.34 & 0.10 \\
2015 & 0.06 & 0.01 & 0.23 & 0.59 & 0.15 \\
Mean value & 0.10 & 0.05 & 0.21 & & \\
\hline
\end{tabular}

Overall, the trade complementarity between China and Vietnam is not strong, and the annual average index is 0.15 . Specifically, agricultural products in category 4 have the strongest inter-industry trade complementarity, with an annual average index of 0.59 , which is much higher than other categories of agricultural products.

"Table IX" shows that the intra-industry trade complementarity between China and Vietnam is relatively low, with an annual average of 0.34 , but the index is increasing year by year, indicating that the intra-industry trade complementarity of China-Vietnam agricultural products is increasing. Specifically, agricultural products in category 1 have the largest index, with an annual average of 0.63 .

From the contrastive analysis on the inter-industry and intra-industry trade complementarity indices, it can be known that the complementarity of intra-industry agricultural product trade between China and Vietnam is higher than that of interindustry trades as a whole, which shows that the agricultural product trade complementarity between China and Vietnam is more based on product heterogeneity, economies of scale, and other advantages. Seeing from the various types of agricultural products, the intra-industry trade complementarity index of agricultural products in category 0 and 1 is much higher than that of inter-industry trade, which shows the great potential for intra-industry trade cooperation on agricultural products in $\mathrm{f}$ category 0 and 1 , and the great potential for inter-industry trade of agricultural products in category 4. It indicates that China and Vietnam should pay attention to the cooperation on intra-industry trade of agricultural products in category 0 and category 1 , and should pay attention to the cooperation on inter-industry trade of agricultural products in category 5 . The inter-industry trade complementarity index of the agricultural products in category 2 is basically the same as the intraindustry trade complementarity index. 


\begin{tabular}{llllll}
\hline Year & Category 0 & Category 1 & Category 2 & Category 4 & $\begin{array}{c}\text { Comprehensive } \\
\text { Agricultural Products }\end{array}$ \\
\hline 2006 & 0.31 & 0.45 & 0.23 & 0.02 & 0.29 \\
2007 & 0.29 & 0.46 & 0.26 & 0.01 & 0.29 \\
2008 & 0.28 & 0.42 & 0.25 & 0.03 & 0.27 \\
2009 & 0.32 & 0.44 & 0.22 & 0.03 & 0.30 \\
2010 & 0.34 & 0.58 & 0.27 & 0.03 & 0.33 \\
2011 & 0.34 & 0.67 & 0.29 & 0.05 & 0.36 \\
2012 & 0.37 & 0.75 & 0.26 & 0.07 & 0.40 \\
2013 & 0.41 & 0.82 & 0.27 & 0.09 & 0.41 \\
2014 & 0.43 & 0.87 & 0.23 & 0.11 & 0.45 \\
2015 & 0.49 & 0.84 & 0.24 & 0.16 & 0.34 \\
\hline
\end{tabular}

\section{CONCLUSION}

\section{A. The Basic Conclusion}

In recent years, with the introduction of "the Belt and Road" strategy, the total trade volume of China-Vietnam agricultural products has increased significantly, and it shows a double growth trend in import and export trade. However, in the trade of agricultural products between China and Vietnam, China is basically in a trade deficit, and the proportion of China-Vietnam agricultural product trade is still at a relatively low level in the trade between the two sides. Seeing from the trade structure of commodities, most of China's agricultural products exported to Vietnam are concentrated in category 05 , 07 and 08. Vietnam's agricultural products exported to China are mainly concentrated in category 05, 07 and 23, which indicates that China-Vietnam agricultural product trade is dominated by intra-industry trade to a certain extent.

From the perspective of the competitiveness of ChinaVietnam agricultural products trade, the import similarity index between China-Vietnam agricultural products trade in major markets is relatively high and the competition is fierce. From the analysis of revealed comparative advantage index, it can be seen that the export competitiveness of China's agricultural products is far lower than that of Vietnam's agricultural products in the world over the same period.

Complementarity analysis shows that the complementarity of China-Vietnam agricultural products trade is generally low, but the trade complementarity of China-Vietnam agricultural products is much higher than that between China and other countries of ASEAN. China-Vietnam agricultural products trade is mainly dominated by intra-industry trade, supplemented by inter-industry trade. This shows that China and Vietnam take the advantages of seasonal differences and geographical advantages to develop intra-industry trade of agricultural products. Specifically, the trade of agricultural products in category 0,2 and 4 is dominated by intra-industry trade, while the trade of agricultural products in category 1 is dominated by inter-industry trade. The complementarity of intra-industry trade of agricultural products between China and Vietnam is higher than that of inter-industry trade as a whole. This shows that the trade complementarity of ChinaVietnam agricultural products is more based on product heterogeneity and economies of scale.

\section{B. Suggestions}

1) Optimize and adjust the structure of China-Vietnam agricultural production trade to realize balanced development:In China-Vietnam agricultural product trade, China has long been in a state of trade deficit, which is partly because of the unbalanced supply and demand of China's domestic agricultural products, besides, the strategy of "the Belt and Road" has reduced the cost of trade between China and countries along the route, leading China to import a large number of agricultural products from countries along "the Belt and Road". In order to reduce the trade deficit between China and Vietnam, the trade structure should be adjusted to achieve a balanced development of bilateral trade.

2) Consolidate the infrastructure construction of ChinaVietnam agricultural product trade: The trade volume of China-Vietnam agricultural products has been continuously increasing in recent years. This does not only benefit from the complementarity of the agricultural product trade between the two sides, but is also closely related to the geographic advantages of the two countries. Vietnam is lagging behind in terms of infrastructure such as road traffic. In order to give full play to its geographical advantages, it improves transportation conditions and reduces the cost of trade logistics. Both sides should make full use of "the Belt and Road" strategy, and realize the interconnection of infrastructure through the Asian Infrastructure Investment Bank, the BRICS Development Bank, etc.

3) Diversify agricultural product varietiesand enrich the agricultural product market: The similarity indices of ChinaVietnam agricultural products in the world market, the American, the EU and the Japanese markets are all at a relatively high level, indicating that the competitiveness of China-Vietnam agricultural products is relatively high. To this end, China and Vietnam should try their best to diversify product varieties and refine export markets to reduce product 
competition, and encourage companies to import Vietnam's advantageous agricultural products and export China's advantageous agricultural products through preferential trade policies.

4) Increase the proportion of trade in China and Vietnam's high value-added agricultural products: The proportion of China-Vietnam agricultural product trade in bilateral product trade is $9.15 \%$. China-Vietnam agricultural products trade is in a relatively small scale, which is mainly because of the fact that China-Vietnam trade is dominated by primary agricultural products with low added value. Therefore, China and Vietnam can expand the deep processing market of agricultural products, and increase the proportion of trade in China and Vietnam's high value-added agricultural products, so as to increase the proportion of China-Vietnam agricultural product trade in bilateral product trade.

5) Use "Internet + Agriculture" to strengthen the export competitiveness of China's agricultural products: The agricultural products exported by China are in a disadvantageous position in the international market. Therefore, in the context of "the Belt and Road," China should make full use of the latest developments in information technology to create chained services of agricultural products trade from production to sales and after-sales. In terms of production, by vigorously advocating Internet + agriculture, we can timely and accurately understand the needs of China and Vietnam's agricultural product markets, and produce marketable products. In terms of sales, we should focus on supporting emerging industries such as cross-border ecommerce of agricultural products, make full use of ecommerce platforms to further promote agricultural product trade, and encourage Chinese and Vietnamese enterprises to promote the import and export of their high-quality specialty agricultural products through e-commerce platforms. In terms of after-sales services, we can establish traceability mechanism, which not only allows customers to understand the detailed product information through the Internet, but also promptly traces responsibility for the defective products.

6) Promote effective joint of "the Belt and Road" and the "Two Corridors and One Circle" : 7 China-Vietnam agricultural product trade is dominated by intra-industry trade, which is particularly evident in category 0,2 and 4, and the complementarity index of intra-industry trade in agricultural products is greater than that of inter-industry trade, which indicates great potential for carrying out intra-industry trade cooperation agricultural products between China and Vietnam. The effective joint of "the Belt and Road" and the "Two Corridors and One Circle" will help expand the trade and investment between the two countries and other countries, continue to develop the market, gradually form strong agglomeration effects and economies of scale, and help increase the level of intra-industry trade between China and

${ }^{7}$ The "Two Corridors and One Circle" refers to the two corridors: "KunmingLao Cai - Hanoi - Haiphong - Quang Ninh", "Nanning - Lang Son - Hanoi Haiphong" and "Beibu Gulf Economic Rim".
Vietnam. It will also create more opportunities for the enterprises in the two countries, especially small and mediumsized enterprises, to participate in the production of regional and global value chains, and the added value of products and industries will be enhanced by using the latest scientific and technological achievements.

\section{REFERENCES}

[1] Balassa B. TRADE LIBERALIZATION AND REVEALED COMPARATIVE ADVANTAGE [J]. Manchester School, 1965, 33(2):99-123.

[2] Finger J M, Kreinin M E. A Measure of "Export Similarity" and Its Possible Uses [J]. Economic Journal, 1979, 89(356):905-912.

[3] Glick R, Rose A K. Contagion and trade: why are currency crises regional? [C].Federal Reserve Bank of San Francisco, 1998.

[4] Ruan Qiujiang. Study on Trade Competition and Complementarity of China-Vietnam Agricultural Products [D]. Hunan University, 2009. 阮 氏秋江. 中越农产品贸易竞争与互补性研究[D]. 湖南大学, 2009.

[5] Chen Xiulian. Study on the Complementarity of Service Trade between China and ASEAN Countries [J]. Finance \& Trade Economics, 2011(6):74-80. 陈秀莲. 中国与东盟国家服务贸易互补性的研究[J]. 财贸经济, 2011(6):74-80.

[6] Yu Miaozhi, Liang Yinfeng, Gao Ying. Competitiveness and complementarity of agricultural products trade between China and South Asia: Taking "the Belt and Road" strategy as the background[J]. Issues in Agricultural Economy, 2016(12):83-94. 余妙志, 梁银锋, 高 颖. 中国与南亚地区农产品贸易的竞争性与互补性一一“一带一 路”战略为背景 $[\mathrm{J}]$. 农业经济问题, 2016(12):83-94.

[7] Yang Lizhuo, Liu Xuejiao, Yu Wence. Study on the Trade Complementarity between China and Central Asian Countries under the Background of "the Belt and Road" [J]. Shanghai Economic Review, 2015(11):94-103. 杨立卓, 刘雪娇, 余稳策. “一带一路”背景下我国与 中亚国家贸易互补性研究 [J]. 上海经济研究, 2015(11):94-103.

[8] Sun Lin. The Competitive Relationship of Agricultural Product Trade between China and ASEAN: An Empirical Analysis Based on the Export Similarity Index $[\mathrm{J}]$. Journal of International Trade, 2005(11):71-76. 孙林. 中国与东盟农产品贸易竞争关系一基于出 口相似性指数的实证分析 [J]. 国际贸易问题, 2005(11):71-76.

[9] Pi Jun, Liu Xiangjun. China-Vietnamese Economic and Trade Relations: An Analysis of Competitiveness and Complementarity [J]. Southeast Asian Affairs, 2009(2):50-57. 皮军, 刘相骏. 中越经贸关系: 竞争性与互补性分析 [J]. 南洋问题研究, 2009(2):50-57.

[10] He Min, Zhang Ningning, Huang Zequn. Analysis of the competitiveness and complementarity of China's agricultural product trade with the countries along "the Belt and Road" [J]. Issues in Agricultural Economy, 2016(11):51-60. 何敏, 张宁宁, 黄泽群. 中国与 “一带一路”国家农产品贸易竞争性和互补性分析[J]. 农业经济问题, 2016(11):51-60.

[11] Qu Ruxiao, Liu Xia. Analysis on the Competitiveness and Complementarity of the Trade between China and Western Asia in the Context of "the Belt and Road" [J]. Journal of International Economic Cooperation, 2017(4):60-66. 曲如晓, 刘霞. “一带一路”背景下中国与 西亚贸易竞争性与互补性分析[J]. 国际经济合作, 2017(4):60-66.

[12] Yu Lixin, Qiu Ying. Reflections on the Strategic Layout of "the Belt and Road" of China [J]. International Trade, 2016(1):14-20. 于立新, 表 芗. 中国“一带一路”战略布局思考[J]. 国际贸易, 2016(1):14-20.

[13] Xu Changwen. Vietnam will become China's largest economic and tr ade partner in ASEAN this year. [J]. International Trade, 2016(6):38-40. 徐长文. 今年越南将成为中国在东盟的最大经贸合作伙伴 $[\mathrm{J}]$. 国际 贸易, 2016(6):38-40.

[14] Zhang Fang. Status quo of fruit production and trade in Vietnam and prospects of China-Vietnam fruit trade, statistics and analysis of fruit production and trade in major countries along "the Belt and Road" (II) [J]. China Fruit News, 2016, 33(3): 28 -40. 张放. 越南水果生产贸 易现状及中越水果贸易前景展望“一带一路”沿线主要国家水果生产 与贸易统计分析(二)[J]. 中国果业信息, 2016, 33(3):28一 - 40. 